\title{
Here and there 2004
}

\author{
David McDonald
}

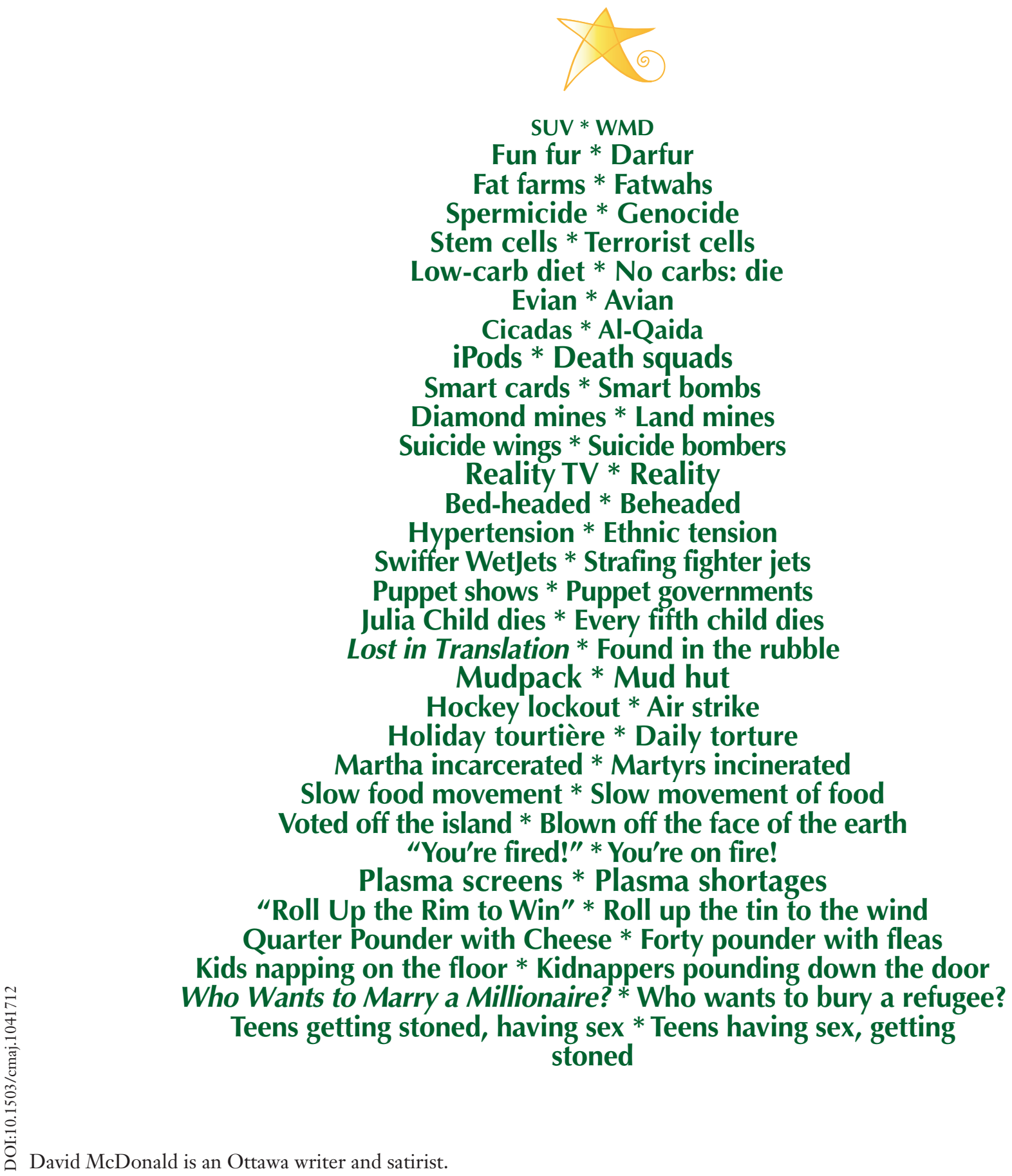

